\title{
Evaluation of the Adaptation Interface of One-Piece Implant-Supported Superstructures Obtained in Ni-Cr-Ti and Pd-Ag Alloys
}

\author{
Heloisa Módena Ferreira da COSTA \\ Renata Cristina Silveira RODRIGUES \\ Maria da Glória Chiarello de MATTOS \\ Ricardo Faria RIBEIRO \\ Department of Dental Materials and Prosthesis, School of Dentistry of Ribeirão Preto, University of São Paulo, \\ Ribeirão Preto, SP, Brazil
}

\begin{abstract}
Several formulations of alternative alloys have been proposed for the substitution of gold-based alloys used in Dentistry. Recently, a $\mathrm{Ni}-\mathrm{Cr}$-Ti-based alloy has been introduced. The purpose of this work was to verify the marginal adaptation obtained with one-piece superstructures for implant-supported prostheses obtained in Ni-Cr-Ti alloy, compared to a semi-noble alloy Pd-Ag. Eight superstructures for each alloy were produced over 4 implants in the anterior region of the mandible. The superstructures were placed in a torquemeter and the fixation screw of implant \#1 was tightened with a $20 \mathrm{Ncm}$ load with the others loosened (Sheffield test). The unfitness (in $\mathrm{mm}$ ) was measured using a three-dimensional optical measurer in each implant, in the buccal and lingual aspects. The obtained data were submitted to statistical analysis by the analysis of variance and Tukey's test at $5 \%$ level. Significant differences were found for the factors material $(\mathrm{p} \leq 0.05)$, with Ni-Cr-Ti pieces better than Pd-Ag ones, and implants $(\mathrm{p} \leq 0.01)$. There were no significant differences for the factor position and interactions among factors $(\mathrm{p}>0.05)$. Based on the analysis of the data, it is possible to conclude that the Ni-Cr-Ti alloy makes possible the obtainment of one-piece implant-supported superstructures with a smaller misfit compared to the one obtained in Pd-Ag alloy, traditionally indicated for this situation. Additional tests may verify the superiority of the $\mathrm{Ni}-\mathrm{Cr}-$ Ti alloy.
\end{abstract}

Key Words: chromium alloys, titanium, implants.

\section{INTRODUCTION}

The large use of osseointegrated implants for oral rehabilitation has led to research so that restorative materials capable of meeting the needs of the stomatognathic system are available to the clinician, dental technician and patient. The concern of prosthetic rehabilitation must be, primarily, in terms of the adaptation of the metallic structures over the prepared dental structures or over the implant cylinder. There is no consensus as to a specific limit of misfit to avoid problems or guarantee success (1-3).

Another important factor to be considered when using alternative alloys is biocompatibility. Several studies show advantages and disadvantages of the use of these alloys $(4,5)$, but few report their effect in the oral environment. Patients in good health and with no allergic reactions to nickel have not shown any problems with these alloys (6); however, there are reports that the most severe tissue response occurs with samples of Ni-Cr alloys and the least with 22-carat gold. Thus, a meticulous anamnesis for the evaluation of possible allergic reactions is vital (7).

Biomechanically, stress transference to implants depends on the distribution of the vertical and lateral loads in relation to the number, arrangement and strength of the prosthetic restoration itself. As the implant is in direct contact with osseous tissue, it will transmit any impact surges applied over itself (8).

Based on these factors, alternative alloys that are

Correspondence: Prof. Dr. Ricardo Faria Ribeiro, Departamento de Materiais Dentários e Prótese, Faculdade de Odontologia de Ribeirão Preto, USP, Av. do Café, s/n - Monte Alegre, 14040-904 Ribeirão Preto, SP, Brasil. Tel: +55-16-602-4005. Fax: +55-16-633-0999. e-mail: rribeiro@forp.usp.br 
biocompatible and also provide acceptable precison of fit, with adequate passivity, are sought (3,9-12).

By the analysis of biomechanical aspects of load distribution between implant-supported and tooth-supported prostheses, it has been concluded that load distribution over implants depends on the level of tissue deformation (13). Taking into account that the periodontal ligament allows movements up to $100 \mu \mathrm{m}$, load distribution over implants is much smaller than over natural teeth, and thus, lack of passive adaptation may lead to a high incidence of fatigue of metal up to its failure $(14,15)$.

If the prosthesis design is adequate, with rigid structure and passive adaptation, the risk of fracture of the components is low. Different protocols have been suggested for the analysis of prosthesis adaptation, and various clinical and technical articles show strategies to improve adaptation of implant-supported prostheses $(16,17)$. Factors which may influence the clinician's decision in the obtainment of passive adaptation include the use of methods, equipment and available components, associated to the experience in the use of these strategies, convenience and time effectiveness (18).

Another study has reported that 100 and $175 \mu \mathrm{m}$ vertical discrepancies lead to significant instabilities of screws in implant-supported complete dentures (19). However, to date, no specific range of misfit has been established, below which problems are minimal and above which failures occur (20).

The aim of this work was to verify the marginal adaptation obtained with superstructures for one-piece implant-supported prostheses produced in Ni-Cr-Ti al-

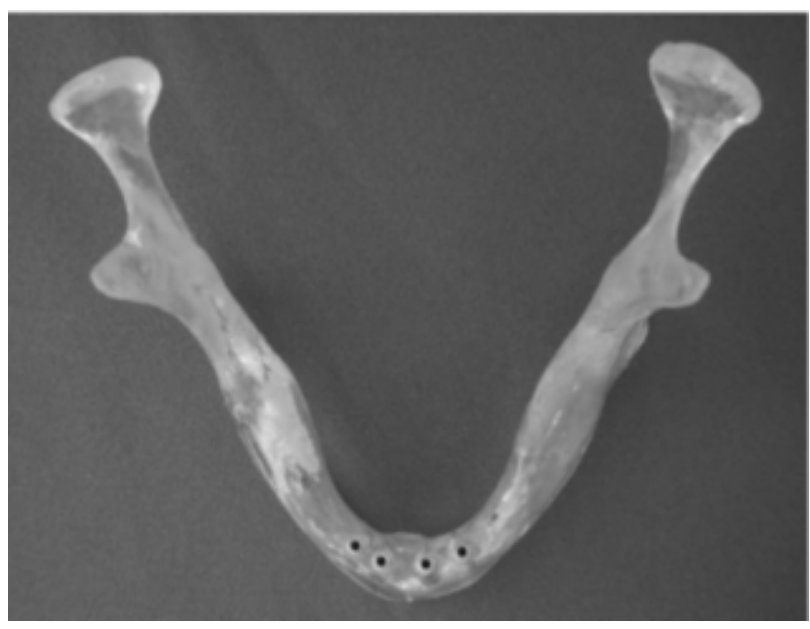

Figure 1. Mandible acrylic replica with implants. loy compared to one obtained with a Pd-Ag alloy (Porson-4), using the Sheffield test.

\section{MATERIAL AND METHODS}

In this work, the Ni-Cr-Ti (Tilite Omega; Talladium Inc., Valencia, CA, USA) and Pd-Ag (Porson 4; Degussa Div. Dental, São Paulo, SP, Brazil) alloys were used.

From an acrylic resin mandible replica on which 4 implants Conexão system (Conexão Sistemas de Prótese Ltda., São Paulo, SP, Brazil), $10 \mathrm{~mm}$ in height and $3.75 \mathrm{~mm}$ in diameter, were placed, a silicone matrix was made, which allowed the obtainment of the working cast used in this study (Figures 1 and 2).

UCLA plastic copings (055CNB, Conexão Sistemas de Prótese) were adapted over each implant and tightened with a $10 \mathrm{Ncm}$ torque on a titanium work screw (119CNB, Conexão Sistemas de Prótese). Cylinder bonding was done with dental floss and acrylic resin (Duralay, Reliance Dental Mfg. Co., Worth, IL, USA). Standard waxing of 16 superstructures was then performed, and the marginal adaptation fit over each implant was verified and corrections were made if necessary.

Following this, the wax patterns were embedded in a quick investment for high fusion (Heat Shock, Polidental, São Paulo, SP, Brazil), and one-piece casted, making two groups of 8 in Ni-Cr-Ti and Pd-Ag. Oxygen-gas flame was used for casting, with a mold temperature of $900^{\circ} \mathrm{C}$, according to manufacturer recommendations, and the alloys were injected into the mold by centrifugation.

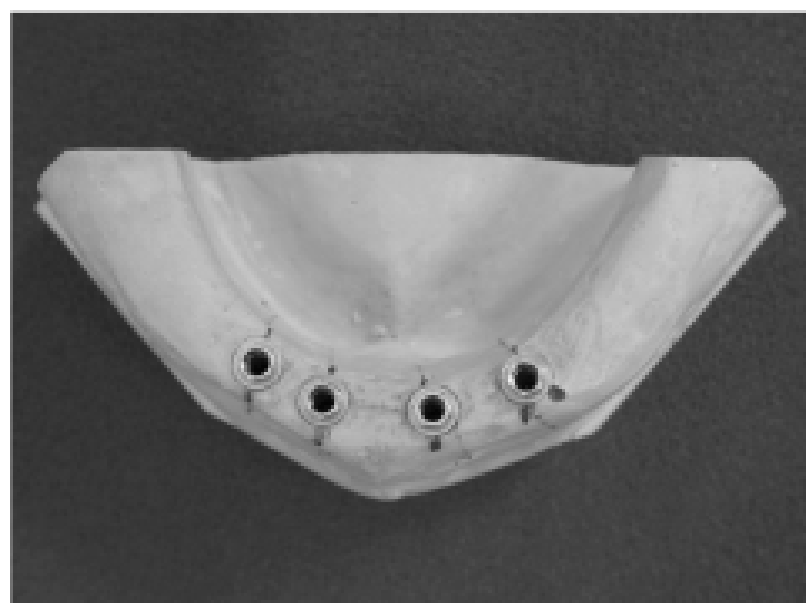

Figure 2. Master cast with implant analogs. 
Following the divestment, the pieces were cleaned and sandblasted with $100 \mu \mathrm{m}$ granulation aluminum oxide $\left(80 \mathrm{lib} / \mathrm{pol}^{2}\right)$. No finishing or polishing procedures were done. Only nodules were carefully removed under magnification.

The measurements were made according to Sheffield's test (18). Only one of the screws was tightened with a $20 \mathrm{Ncm}$ torque, at implant \#1. The readings were done in a three-dimensional optical measurer (RAM Optical Instrumentation Inc., Irvine, CA, USA) at buccal and lingual aspects of each implant, based on reference lines traced on the work cast. For this, the posterior extension of the original gypsum cast was cut in order to allow the placement, always at the same position, during the readings of the fit interfaces between implant/superstructure. Three readings (buccal and lingual) were made for each implant by the same operator and a mean value was obtained.

Data was submitted to statistical analysis by ANOVA for 3 criteria (material, position and implant). When significant differences were indicated, a complementary Tukey's test was applied $(\mathrm{p}<0.05)$.

\section{RESULTS}

The results of ANOVA for the variable fit interfaces, regarding the causes of variation (factors) in the study, are shown in Table 1.

Figures 3-6 show the interfaces between implant and metallic structures on implants \#1 and \#4 during the Sheffield test

Using ANOVA and Tukey's test, significant differences were found for the factors material $(p \leq 0.05)$, with Ni-Cr-Ti pieces presenting smaller fit interfaces than Pd-Ag ones, and implants ( $p \leq 0.01)$. There were no significant differences for the factor position and interactions among factors $(\mathrm{p}>0.05)$.

\section{DISCUSSION}

Although the effectiveness and reliability of several oral rehabilitation procedures have already been mastered, new alternatives have been sought due to the high incidence of total and partial edentulism and the increase of population's life expectancy, mainly to make these procedures more accessible.

In order for rehabilitation treatments to meet their basic aims, it is necessary that a set of factors be obtained: passivity, perfect occlusal adjustment and the use of biocompatible materials (3-5,9-12).

The construction of implant-supported prostheses is a reality and has reached success levels that vouch for its effectiveness when well planned and performed. Based on this success, many researchers have proposed alternative techniques and materials, which make this treatment modality available to a higher number of patients while maintaining effectiveness $(1,2,6,8,9)$.

The metallic alloy used has a vital role and its properties determine the later selection of all prosthetic components. Several important factors to be considered are biocompatibility, low specific weight, modulus of elasticity near the implant metal, corrosion strength, low potential of releasing components from the alloy, indicated handling technique and accessible cost $(4,5,10,11)$.

The most used material for the construction of osseointegrated implants is titanium. Thus, a metal for the confection of prostheses is sought which relates with titanium from the implants without the possibility of galvanism and, thus, without reactions due to sensitivity to elements released by the alloys. However, titanium's high melting point and reactivity and characteristics such as: low capacity to reproduce details, interaction of the surface with the investment and

*Significant by $\mathrm{F}$ test, at $5 \%$ level $(\alpha \leq 0.05)$.

**Significant by $\mathrm{F}$ test, at $1 \%$ level $(\alpha \leq 0.01)$. 

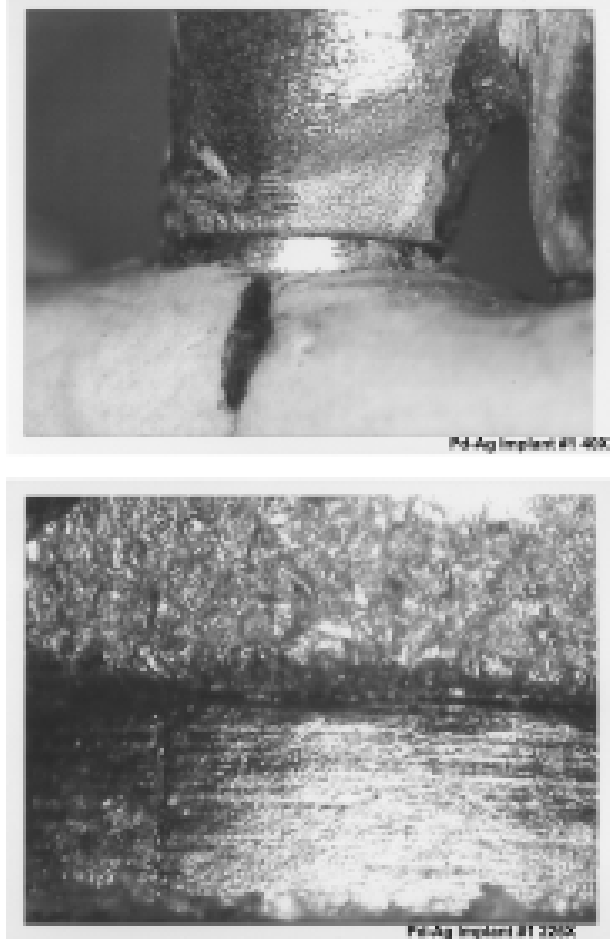

Figure 3. Pd-Ag alloy. Fit interfaces during Sheffield test of structure \#1, implant \#1. Magnification: top, 40X; bottom, 226X.
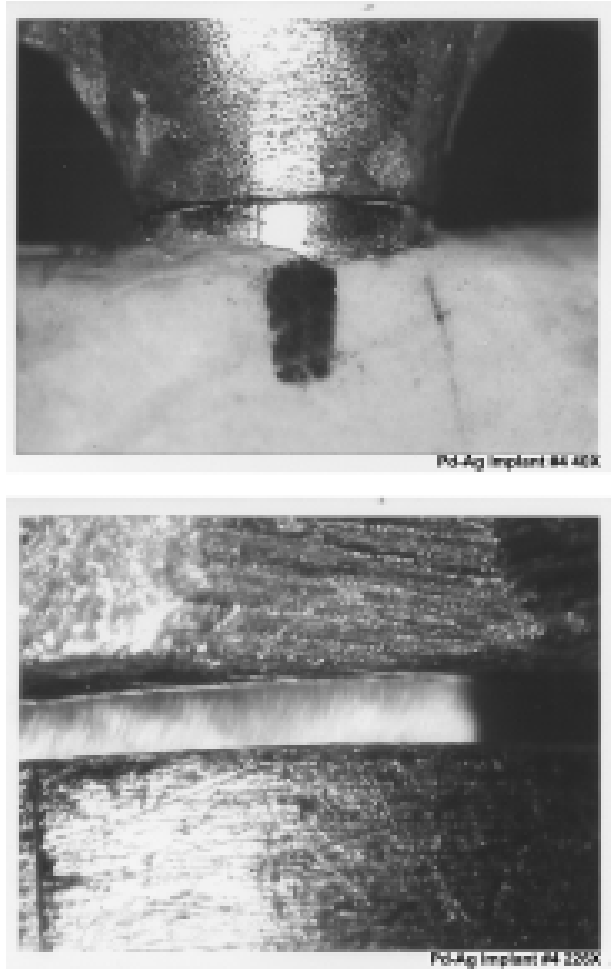

Figure 5. Pd-Ag alloy. Fit interfaces during Sheffield test of structure \#1, implant \#4. Magnification: top, 40X; bottom, 226X.
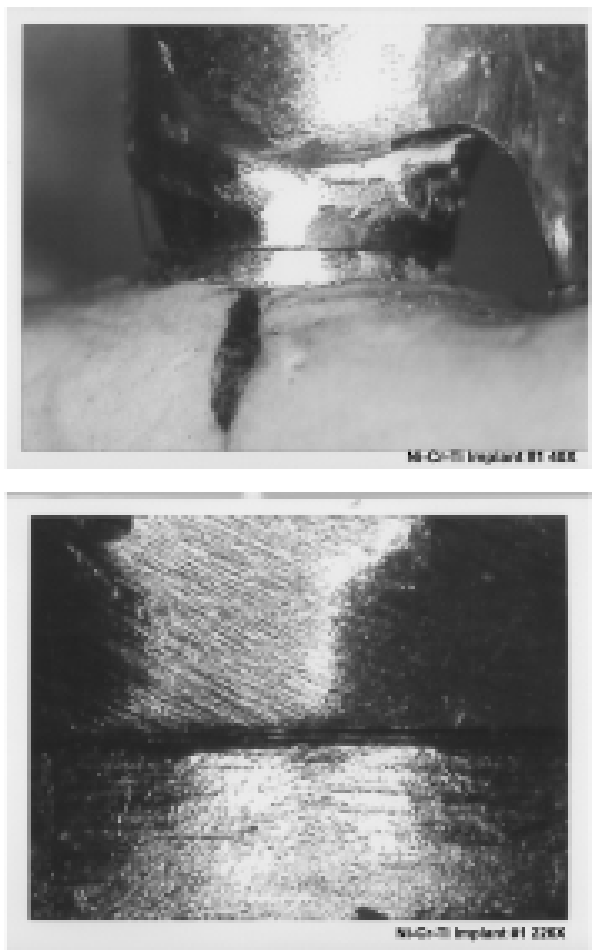

Figure 4. Ni-Cr-Ti alloy. Fit interfaces during Sheffield test of structure \#1, implant \#1. Magnification: top, 40X; bottom, 226X.
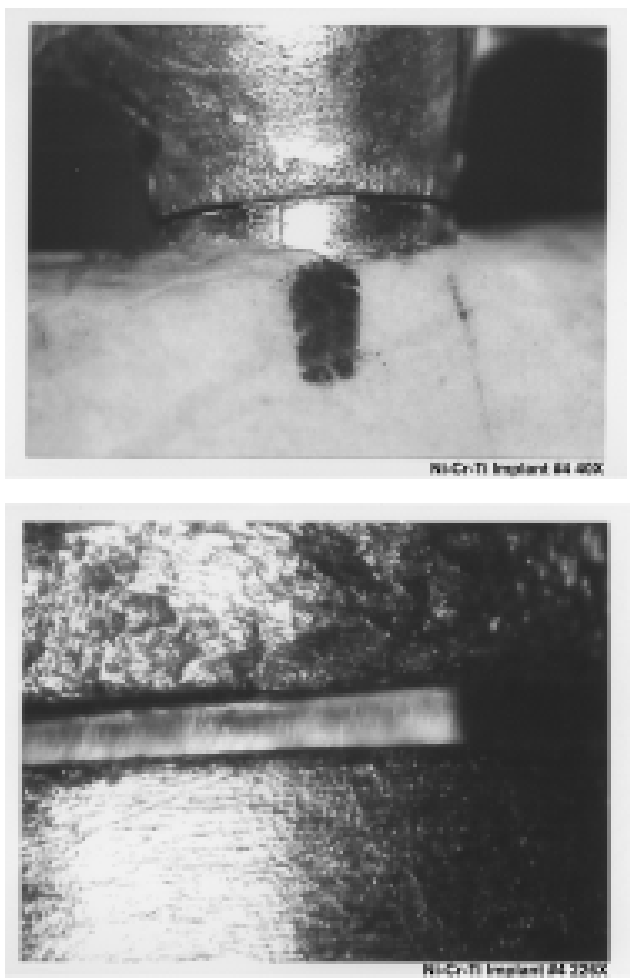

Figure 6. Ni-Cr-Ti alloy. Fit interfaces during Sheffield test of structure \#1, implant \#4. Magnification: top, 40X; bottom, 226X. 
the development of porosities are responsible for difficulties in its adaptation, besides the need for the use of plastic calcinable cylinders $(3,6,7,11,13,15,16,18)$.

In this study, superstructures made of Ni-Cr-Ti and Pd-Ag alloys were constructed, proposed by the manufacturers as alternatives to currently available ceramic noble alloys. The latter was used as control due to its success reported in the literature (13). By observing the results obtained in this study, it was possible to verify significant differences between the materials used $(p=0.05)$ with lower values of unfitness for Ni$\mathrm{Cr}-\mathrm{Ti}$ alloy, which would make it an important alternative. The cost of these alloys must also be considered. On the Brazilian market, Ni-Cr-Ti alloy was being sold at US\$0.64/gram, while Pd-Ag alloy was being sold at US\$14.94/gram.

The search for prostheses with passive seating, without causing tension to components and bone is one of the most cited requirements in publications that analyze implant-supported prostheses $(3,6,8,9,12,14)$. Nevertheless, there is no consensus in relation to how to evaluate this or the best way to obtain it $(15,18)$. The methodology used (Sheffield test) allowed the detection of distortions during casting, indicating significant differences $(p=0.05)$ for the adaptation of different implants. Again, the Ni-Cr-Ti alloy was superior to the Pd-Ag alloy. The figures show our results, which were similar to those of other authors $(2,3,12,15-19)$.

Diverse interactions analyzed did not show significant differences $(\mathrm{p}>0.05)$, indicating that good and bad results may be obtained with both materials, depending on the operating quality to which they are submitted.

No alloy is ideal in all aspects. When compared to noble alloys, alternative ones have higher values of hardness and modulus of elasticity, are more resistant at high temperatures, but may be difficult to cast and weld. The Ni-Cr-Ti alloy used was cast under oxygen-gas flame, one of the alternatives recommended by the manufacturer, and did not show any problem during its processing, suggesting large working easiness, when instructions are correctly followed (7).

Also, according to the manufacturer, the leftovers obtained from the casting procedure of the Ni-CrTi alloy may be used again, which would guarantee an even greater reduction in the final cost of the work.

New studies must be performed to validate these findings and investigate other important characteristics to confirm the advantage of using Ni-Cr-Ti alloys in the construction of prosthesis metallic structures.

\section{RESUMO}

Várias formulações de ligas alternativas têm sido propostas para a substituição das ligas áureas na Odontologia. Recentemente foi lançada uma liga à base de $\mathrm{Ni}-\mathrm{Cr}$-Ti. $\mathrm{O}$ propósito deste trabalho foi verificar a adaptação marginal de supra-estruturas de próteses implanto-suportadas obtidas em liga de $\mathrm{Ni}-\mathrm{Cr}-\mathrm{Ti}$, comparada às obtidas em liga seminobre de Pd-Ag. Foram confeccionadas 8 supra-estruturas de cada liga, sobre 4 implantes na região anterior da mandíbula. As supra-estruturas foram posicionadas e o parafuso de fixação do implante \#1 foi apertado com carga de $20 \mathrm{Ncm}$ num torquímetro, ficando os demais desparafusados (teste de Sheffield). A desadaptação (em $\mathrm{mm}$ ) foi medida num medidor óptico tridimensional, nas faces vestibular e lingual de cada implante. Os dados foram submetidos à análise estatística pela análise de variância e teste complementar de Tukey em nível de $5 \%$. Na análise dos dados foram encontradas diferenças significantes para os fatores material, em nível de $5 \%(\mathrm{p} \leq 0.05)$, com melhores resultados para estruturas em $\mathrm{Ni}-\mathrm{Cr}-\mathrm{Ti}$, e implantes, em nível de $1 \%(\mathrm{p} \leq 0.01)$. Não houve diferença significante para $o$ fator posição e para as interações entre fatores $(p>0.05)$. Com base na análise dos dados pode-se concluir que a liga de Ni-CrTi possibilita a obtenção de supra-estruturas implanto-suportadas em monobloco com desadaptação menor se comparada à das obtidas em liga de Pd-Ag, tradicionalmente indicada para esta situação. Testes adicionais poderão atestas a superioridade da liga de Ni-Cr-Ti.

\section{REFERENCES}

1. Branemark PI. Osseointegration and its experimental background. J Prosthet Dent 1983; 50:399-409.

2. Holmes JR, Bayne SC, Holland GA, Sulik WD. Considerations in measurement of marginal fit. J Prosthet Dent 1989;62:405-408.

3. Wee AG, Aquilino SA, Schneider RL. Strategies to achieve fit in implant prosthodontics: a review of the literature. Int $\mathrm{J}$ Prosthodont 1999;12:167-178.

4. Wataha JC. Biocompatibility of dental casting alloys: a review. J Prosthet Dent 2000;83:223-234.

5. Sjogren G, Sletten G, Dahl, JE. Cytotoxicity of dental alloys, metals, and ceramics assessed by Milipore filter, agar overlay, and $\mathrm{mtt}$ tests. J Prosthet Dent 2000;84:229-236.

6. Skalak, R. Biomechanical considerations in osseointegrated prostheses. J Prosthet Dent 1983;49:843-848.

7. Hulterström M, Nilsson U. Cobalt-chromium as a framework material in implant-supported fixed prostheses: A 3 year followup. Int J Oral Maxillofac Implants 1994;9:449-454.

8. Jemt T. Failures and complications in 391 consecutively inserted fixed prostheses supported by Branemark implants in edentulous jaws: a study of treatment from the time of prosthesis placement to the first annual checkup. Int $\mathbf{J}$ Oral Maxillofac Implants 1991;6:270-276.

9. Weinberg LA. The biomechanics of force distribution in implantsupported prostheses. Int J Oral Maxillofac Implants 1993;8:1931.

10. Kansu G, Aydin AK. Evaluation of the biocompatibility of vari- 
ous dental alloys: Part 1 - Toxic potentials. Eur J Prosthodont Restor Dent 1996;4:129-136.

11. Townsend LWA, Griswold WH, Vermilyea SG. Preliminary observations on clinical use of a base metal casting alloy. J Prosthet Dent 1984;52:370-374.

12. Jemt T. In vivo measurements of precision of fit involving implant-supported prostheses in the edentulous jaw. Int J Oral Maxillofac Implants 1996;24:138-157.

13. Marker JC, Goodkind RJ, Gerberich WW. The compressive strength of nonprecious versus precious ceramometal restorations with various frame designs. J Prosthet Dent 1986;55:560-567.

14. Kunavisarut C, Lang LA, Stoner BR, Felton DA. Finite element analysis on dental implant-supported prostheses without passive fit. J Prosthodont 2002;11:30-40.

15. Helldén LB, Dérand T. Description and evaluation of a simplified method to achieve passive fit between cast titanium frameworks and implants. Int J Oral Maxillofac Implants 1998;13:190-196.
16. Tipton PA. Maximizing aesthetics, fit, and maintenance of the full-arch implant-supported porcelain-fused-to-metal restoration. Pract Proced Aesthet Dent 2002;14:395-400.

17. Iglesia MA, Moreno J. A method aimed at achieving passive fit in implant prostheses: case report. Int J Prosthodont 2001;14:570574.

18. Jemt $\mathrm{T}$. Three-dimensional distortion of gold alloy casting and welded titanium frameworks. Measurements of the precision of fit between completed implant prostheses and the master cast in routine edentulous situations. J Oral Rehabil 1995;22:557-564.

19. Hecker DM, Eckert SE. Cyclic loading of implant-supported prostheses: changes in component fit over time. J Prosthet Dent 2003;89:346-351.

20. Rubeling G. New techniques in spark erosion: the solution to an accurately fitting screw-retained implant restoration. Quintessence Int 1999;30:38-48. 